\title{
Article \\ An Incarnational Pneumatology Based on Romans 8.18-30: The Spirit as God's Solidarity with a Suffering Creation
}

\author{
Matthias Wenk ${ }^{1,2}$
}

Citation: Wenk, Matthias. 2022. An Incarnational Pneumatology Based on Romans 8.18-30: The Spirit as God's Solidarity with a Suffering Creation. Religions 13: 191. https:// doi.org/10.3390/rel13030191

Academic Editor: Joel B. Green

Received: 26 January 2022

Accepted: 21 February 2022

Published: 23 February 2022

Publisher's Note: MDPI stays neutral with regard to jurisdictional claims in published maps and institutional affiliations.

Copyright: (C) 2022 by the author. Licensee MDPI, Basel, Switzerland. This article is an open access article distributed under the terms and conditions of the Creative Commons Attribution (CC BY) license (https:// creativecommons.org/licenses/by/ $4.0 /)$.
1 Institut für Gemeindeorientierte Weiterbildung, 8005 Zurich, Switzerland; m.wenk@bewegungplus.ch

2 BewegungPlus, 3400 Burgdorf, Switzerland

\begin{abstract}
In this article, I argue that scholars of the field of New Testament theology need to be familiar with and listen to the various voices in the discourse of contemporary Christian spirituality in order to give voice to the ancient texts, as well as hear them in new ways. Based on Romans 8.18-30, I want to illustrate how the field of New Testament theology can contribute its voice to the contemporary (western) discussion on ecology, social justice, and power and at the same time enrich a spirituality of solidarity. For this purpose, I will contrast those voices within "pneumatological discourse" in Christian spirituality, which associates the work of the Spirit mainly with the improvement of one's personal life, to Romans 8.18-30, a text central for Pauline pneumatology. I will argue that it represents a cosmic and eschatological outlook and fosters a Christian ethos of walking with the Spirit; taking side with a creation longing and groaning for redemption. This aspect has not received much attention, but is vital for a robust Christian spirituality, especially in regard to an ecological theology and a more nuanced understanding of power.
\end{abstract}

Keywords: Romans 8.18-30; Pauline pneumatology; missio spiritu; Spirit as solidarity; Pauline Ethics; cosmic redemption

\section{Introduction}

\subsection{New Testament Theology and Contemporary Christian Faith and Spirituality:} A Needed Dialogue

In an article that stirred up a vivid discussion on the very culture of discussion in Switzerland, Bruno Ziauddin laments that today the formation process of a political opinion is mainly taking place among peers and in dialogue with people already known to share one's own view; there is no real dialogue taking place anymore. The result is, according to Ziauddin, that many people are no longer willing (or even able) to listen to voices that do not confirm their own viewpoint (Ziauddin 2021). However, living in a complex world demands that we listen to the many tongues and voices in it in order to be able to live together in this world. One such strange and old voice is the Bible, and this voice may help us receive different and new perspectives on pressing issues of our time. However, if and in what way the biblical voice can contribute to contemporary discussions still is a matter of debate. Two of the more recent publications that address the questions if and how the biblical canon can help us particularly in contemporary ethical discussions are Bibelhemeneutik und Sozialethik (Heimbach-Steins and Steins 2012) and Key Approches to Biblical Ethics. An Interdisciplinary Dialogue (Rabens et al. 2021). The field of biblical and/or New Testament theology can also help the Christian churches in a twofold way, cultivating the ability to listen to different voices and thereby gaining new insights for our lives together in this world. First, it helps us to listen carefully to a voice that is definitely not reflecting our own viewpoint and time, nor is it simply confirming our own presuppositions or addressing just the concerns of our own agenda. Second, the canon reflects in itself a role model of giving room to different voices. New Testament (biblical) theology precisely wants to carefully listen to each particular voice represented in the 
canon: New Testament theology seeks "both to describe each document's theology, and to engage theologically with it, noting also its canonical context and any specific influence it may have had on the history of Christian faith and life" (Bauckham 2003). In order to be heard and to contribute to the contemporary discourse on Christian faith and life, scholars working in the field of New Testament theology should carefully listen to the voices of the global Christian community and be acquainted with the major trends and developments of contemporary spirituality (the Christian faith and life). An excellent example of such a dialogue of academics listening to non-academic voices and their understanding of biblical texts is Pascal Bazzell's study of urban ecclesiology (Bazzell 2015).

In listening to such voices, New Testament scholars can, in turn, give voice to the New Testament authors and at the same time hear these authors in a new way. In addition, these non-academic voices are often very influential in the faith and life of many Christians and churches around the globe, and not dialoguing with them deprives both sides of vital benefits.

\subsection{The Aim of the Article}

In this article, I want to illustrate how the field of New Testament Theology can contribute to the contemporary discussion in the churches of the Western hemisphere on ecology, social justice, and ethics in general and, at the same time, enrich a spirituality of solidarity and how the theology of one particular text may have an influence on Christian faith and life in our time. For this purpose, I will focus on the role of the Spirit in Romans 8.18-30. I have chosen this passage for several reasons: Especially in German-speaking Europe, the notion of "spirit" mainly is associated with the non-material world, pure reason or pure beauty, Geist being that which takes us beyond and above nature. Hence, the semantic field of "spirit", at least in German, refers mainly to the non-material and/or the invisible world. This understanding of "spirit" in turn impacts, often unconsciously, many contemporary books and approaches to a pneumatic spirituality: The Spirit of God is to take the believer out of and above this world; the Spirit of God being mainly associated with optimizing the personal life, morally (Bernhardt 2015), financially (Benson 2018), and in terms of health (Medic and Blain 2013) and power (Roberts 2002; Hagin 2012). This, in turn, fosters a spirituality in which the Spirit of God is predominantly associated with "success-stories", the well-being and improvement of life as well as with the realm of the super-natural: the Holy Spirit offers a happy, healthy, and successful life, as presented daily in commercials. All of this leaves people confronted in their lives with even more pain, loss, and failure, with a feeling of being Spirit-abandoned. Further, Romans 8.18-30 represents a text with an apparent cosmic and eschatological outlook, and it is a text that is vital in Paul's theology far beyond its pneumatological or eschatological implications. N.T. Wright remarks that these verses have too often been downplayed in much exegesis, but they are precisely the climax of Paul's argument in Romans 8; indeed, Romans 8 is the central section of Paul's most important letter, it represents "the final great act of covenant renewal and vindication" (Wright 2003, p. 258). Already earlier, Ernst Käsemann has noted: "If Marcion was forced by the inner logic of his theology to cut out vv. 18-22, he is followed today by an existentialism which individualizes salvation and thereby truncates Paul's message by describing freedom formally as openness to the future" (Käsemann 1971, p. 236).

In this article, I will also try to display one perception of the work of the Holy Spirit presented in the New Testament that often is neglected, both in New Testament pneumatology (i.e., Haacker 2003, p. 75) and in contemporary spirituality: The Holy Spirit as God's solidarity with life that is suffering and groaning for liberation. In order to do so, the leading question will be: How does Romans 8.18-30 describe the Spirit working on behalf of this world; what embodies the Missio Spiritu in this world? The question, therefore, is not how or what typifies, according to Romans 8.18-30, the work of the Spirit in a person's or in the church's life, as, e.g., in Galatians 5.16-26. The question is more fundamentally asking for the ethos of the Spirit or his mission: What is the Spirit doing, where is he working, and how is he working ? $^{1}$ Thereby, I will be asking for the mission of the Spirit exemplified in 
this passage, and how the community of God's people can participate in it. Ultimately, I will argue that Romans 8.18-30 is crucial for an "incarnational theology", not only in terms of Christology but also of pneumatology: ${ }^{2}$ By pressing into this material world (cf. Gen. 1:1) and taking side with creation and all forms of life that are threatened by caducity, the Spirit participates in the liberation of this creation. At the end, I will delineate some possible contributions Romans 8.18-30 can make in the contemporary discussion of the mission and ministry of church, particularly the church in the Western hemisphere. However, it needs to be noted that Paul presents neither a detailed nor a systematic presentation of a pneumatological social ethics or an eco-theology in this passage. He rather delineates the larger, cosmic, frame within which he addresses particular ethical issues later in his letter (Rm 12-15); Romans being a letter and not a systematic treatise. In order to develop a thorough pneumatological eco-theology (or social ethics), scholars from the field of New Testament Theology need to listen to other voices, both from the past and contemporary. Voices of the past may include the German nun Hildegard of Bingen with her pneumatological vision of creation or Saint Francis of Assisi and his spirituality of solidarity with all of creation. For a thorough eco-theology, contemporary voices from around the globe must be included in this dialogue, both academic and non-academic as well as both theological and non-theological.

\section{Paul's Pneumatological-Based Soteriology and Social Ethics in Romans 8.18-30}

\subsection{Soteriological Considerations Based on Romans 8.18-30}

\subsubsection{The Redemption of Creation}

For any consideration of the Spirit's role in redemption, Romans 8.1-30 proves itself to be of crucial importance. Already in the first 17 verses of chapter 8, Paul unfolds his understanding of justification and of the new identity of the believers from a pneumatological perspective. In sum, Paul argues that, independent from the law, God is creating for himself a new people by the Spirit, comprising both Jews and gentiles. The reconciling power manifested in this redemptive creation is of eschatological importance for all of creation, for the final redemption of this reconciled people of God will become the very liberation of all of creation. ${ }^{3}$ The ultimate culmination of his soteriological vision is found in the apostle's statement regarding the redemption of the entire creation: " ... creation itself will be liberated from its bondage to decay and brought into the glorious freedom of the children of God" (Rm. 8.21; NIV), or, as Yates notes: "In these verses [8.18-30] Paul's thought gradually shifts from the resurrection of those individuals who are in Christ, to a vision of the renewal of all of creation at the eschaton" (Yates 2008, pp. 151-51; similarly Rabens 2010, p. 209). This shift of focus from a discussion of the Spirit's role in an individual believer to its cosmic dimension is crucial and is also reflected in passages such as Ezekiel 36.26-35, where the renewal of Israel is said to lead to a renewal of creation so that it becomes a new garden of Eden (Yates 2008, p. 153). Passages like Isaiah 32.15-18 also speak of the renewing and life-giving power of the Spirit and its effects on all of creation and are in the backdrop of Romans 8.18-30. Hence, it may not suffice to reduce the Spirit's role in Romans 8.1-30 merely to reveal to "each Christian the supreme significance of the death and resurrection of Jesus Christ in God's redemptive plan" (Menzies 1991, p. 282), but rather at the centre of Paul's interest in Romans 8 is not an individualized soteriology (cf. Rm. 8.17) but the renewal of all that God has created. Haacker emphatically notes that "the glory (literally 'radiance') to be revealed is described as sharing the status of Jesus as brothers and sisters of God's firstborn Son (vv. 29-30)" (Haacker 2003, p. 75). The passage clearly represents a cosmic perception of liberation.

Paul further argues in this passage that the salvation already experienced now by the children of God (including the reconciled relationship between Jews and gentiles) testifies to the eschatological breaking in of God's salvation for all of creation: through the community of faith's present experience of salvation and through the work of the Spirit, it becomes evident here and now what the future reality of all of creation will be like. What exactly comprises the work of the Spirit according to Romans 8.18-30 will be elucidated below. 


\subsubsection{The Spirit and the Redemption of Creation}

Not only does Paul unfold in this passage a soteriology that goes far beyond an individual person's salvation to include all of creation, but he also develops his argument from a pneumatological rather than a purely Christological argument. Instead of relating the eschatological salvation of creation to the Parousia of Christ, he links it to the work of the Spirit ${ }^{4}$ : The Spirit that indwells the risen Christ (Rom. 8.11) ${ }^{5}$ is the guarantee for the eschatological and universal fulfilment of salvation, which will be the final reality for all of creation. And because this final salvation has yet to come, Paul defines the triumph of the children of God (Rom. 8.1-17) as a salvation "in hope". Regarding this hope, Rudolf Bultmann has aptly noted: "If hope is fixed on God, it embraces at once the three elements of expectation of the future, trust, and the patience of waiting" (Bultmann 1964, p. 531). All three aspects of this hope are present in Romans 8.18-30: (a) expectation of the future liberation (Rm. 8.21); (b) trust, based on the work of the Spirit in raising Jesus from the dead (Rm. 8.24-25, 28); and (c) the patient (eagerly) waiting for the final liberation of both the believers as well as of all of creation (Rm. 8.19, 23).

In addition Paul makes it clear that there is no final salvation through the Spirit for those who cry "Abba Father" and who are glorified with Christ (Rom. 8.17), without the liberation of all of creation yet to come: 6 "Spirit possession in no way causes any distance between Christians and creation but rather leads them into solidarity with it, because their final redemption is to serve all of creation to be liberated from the enslavement by demise" (Wilckens 1993, p. 158, own transl.).

Based on the Spirit indwelling the resurrected Christ from, Romans 8.18-30 presents the role of the Spirit until the final liberation of creation in a threefold manner:

- He intercedes before God on behalf of the believers in their present pain and sufferings and thereby helping them to bridge the time between now and their final redemption. ${ }^{7}$

- By the indwelling of the Spirit of God, the believers participate in the resurrection of Christ (Rm. 8.11). This participation becomes the guarantee for their own resurrection and the liberation of all of creation.

- Until the eschatological liberation, the Spirit is God's solidarity with a creation groaning and suffering.

This threefold role of the Spirit becomes even more evident if looking at the formulation "first-fruit of the Spirit" ( $\dot{\alpha} \pi \alpha \varrho \chi \eta े v \tau o \tilde{v} \pi v \varepsilon \dot{v} \mu \alpha \tau o \zeta)$. The most obvious reading of this

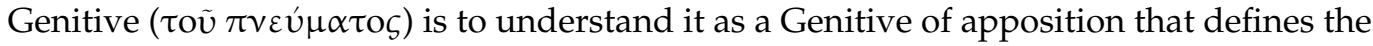
nature of the fruit. In this case, the Spirit itself is the first fruit. However, understanding the formulation as a Genitive of qualification (Genitivus Qualitatis), it is the Spirit that brings forth the first fruit in the life of the believers (similarly: Yates 2008, p. 154). Hence, the Spirit given to the believers is not only the first fruit (God's down payment of salvation); rather, the Spirit already here and now effects the first fruits of the eschatological salvation in the life of the believers: (a) the Spirit stirs up hope in the lives of Christians, (b) the Spirit intercedes for them in times of weakness, and (c) the Spirit groans in solidarity with all of creation. Such are the first fruits of his mission here and now. In his solidarity with all of creation, the same Spirit that indwells the risen Christ is the guarantee that all of creation, which is subject to decay, will have a future that cannot be destroyed anymore.

The Spirit's soteriological work in Romans 8 can best be described with the terms of new life, hope, solidarity, and intercession for a creation that is suffering, including the people of God threatened in this present time. In his solidarity, the Spirit endures the pain of a groaning creation and is longing for its liberation along with it. At the same time, he is interceding on behalf of creation in a way that it cannot do for itself. In addition, he assures that his solidarity with creation becomes visible in and through the church in the midst of the present reality that still is characterized by lack of salvation. On a side note, it may be important to note that Paul in Romans 8.18-30 is not talking about the sufferings "on behalf of Christ" as he does in 1 Cor 4.10-13, 2 Cor 1.5, or even just before in Romans 8.17. Although Paul speaks in Romans 8.35-36 of the sufferings on behalf of Christ, it seems that 
the sufferings in Romans 8.18-30 represent life's struggles and pains in general; creation and life in general are still threatened and subject to demise: "For I made the world for their sake, and when Adam transgressed my statures, what has been made was judged. And so entrances of this world were made narrow and sorrowful and toilsome; they are few and evil, full of dangers and involved in great hardships" (4 Ez. 7.11-12, Metzger 1983). This is similar to Paul's "pain of childbirth" in Romans 8.22. Creation endures these sufferings precisely because it has not yet been raised with Christ to the newness of life and because all of creation is not with Christ yet, the Spirit is in the meantime with all of creation (Rm. 8.26). While addressing the hope evidenced in Romans 8, J.L. Story in his article on Christian affections and Romans 8 surprisingly addresses the solidarity, the groaning with of the Spirit (Story 2021, pp. 204-8), nowhere, an aspect that would have enriched his overall argument.

\subsubsection{The Spirit as God's Solidarity with Creation Waiting for Its Redemption}

In Romans 8.18-30, Paul not only develops his soteriology from a pneumatological rather than a Christological perspective, but he also associates other topics with the Spirit that both in theology as well as in Christian spirituality are normally associated with Christology. This is especially the case with the subject of solidarity: As it is common in Christology to speak of the crucified Jesus as God's solidarity with the suffering creation, ${ }^{9}$ in Romans 8.18-30, Paul links God's solidarity with a suffering and threatened creation to the Spirit. Romans 8.18-30 also reflects a voice for which it is self-evident that there is no personal liberation without the liberation of the soil upon which we stand. Already in the Old Testament, the anticipated eschatological renewal through the outpouring of the Spirit often is described in terms of a renewal of creation (Is. 32.15-18; Ez. 36,25-35), and Paul seems to drink from this fountain in Romans 8.18-30. Further, Paul's emphasis on the Spirit's solidarity with a suffering and groaning creation is only surprising if one limits the Spirit's role in Pauline theology to the transforming power (dynamis) of God. It seems, however, that at least in Romans 8.18-30, the Spirit's presence and activity in this world is also associated with his emphatic-enduring power: The Spirit is the life-giving Spirit, and wherever life is impeded, the Spirit is grieving. Paul's reference to the groaning and grieving of the Spirit in Romans 8.18-30 is not unlike Ephesians 4.30 and the call "do not

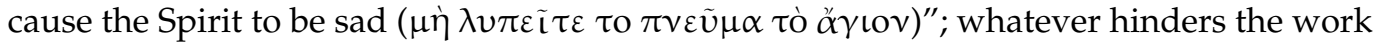
of the Spirit in this world is grieving the Spirit and thereby hindering life to flourish. The contrast between impeding the Spirit, and thereby making communal life impossible, and the work (fruit) of the Spirit that enables communal life is also reflected in Paul's discussion on the work of the "flesh" and the fruit of the Spirit (Gal. 5.13-26); all aspects of the fruit of the Spirit represent relational categories, including joy (rejoicing with).

Romans 8.18-30 represents a voice that adds an aspect often neglected in the discussion of the transforming power of the Spirit: the empowerment to live in and to endure solidarity with a suffering and groaning creation. The text also reflects a voice in which the Spirit of God not only guarantees the salvation accomplished in Christ until its eschatological fulfilment but the Spirit himself is the subject working towards the salvation of all of creation. Ultimately, it is the Spirit of Christ who will give new life to all of creation. Thereby, he will liberate all of life so that it cannot be extinguished anymore.

If in Romans 8, the Spirit is presented as an active subject towards salvation of his own right, it is important to rediscover the role of the Spirit in God's overall story of salvation as Frank Macchia has begun to do (Macchia 2010), so that the discussion on soteriology will truly be Trinitarian. Not only would a "soteriology of the Spirit" broaden the oftentimes judicial outlook of western soteriology, but it would also include such themes as the resurrection and newness of life (the ecological dimension of salvation) as well as the reconciliation among people as vital aspects of soteriology (i.e., Eph 1.10 and 2 Cor 13.13). With the inclusion of the social and cosmic dimension of God's work for all of life, the "soteriological vision" of the church would be broadened and reflect more accurately God's passion for this world. 


\subsubsection{Summary of the Spirit's Role in Salvation}

In Romans 8.18-30, the Spirit has his own role to play in the story of salvation. His role in the redemption of this world can best be summarized in a twofold way: (a) the creation/liberation of life and (b) his solidarity with a world that is suffering and groaning for its final liberation. Both of these reasons are enough for hope in the midst of despair, because the Spirit is "the bridge over troubled water" that carries the believers until they participate in the unlimited joy of their final salvation, or, to express it in terms of the missio spiritu (the ethos of the Spirit) exemplified in Romans 8.18-30, until the final re-creation and liberation of life, the mission of the Spirit leads him into the present-day pains and conflicts of creation in order to join in solidarity into its cry for salvation and then to offer this very cry to God. Since God's salvific intervention in this world has always become paradigmatic for the church's way of living in this world (the ethos of God as a source for the church's ethics), it is now that we have to consider some social-ethical (as well as missional) implications based on such an "incarnational pneumatology".

\section{Sharing the Ethos of the Spirit: Social-Ethical Considerations}

I will now delineate some implications for the ethical discussion of the church, especially the Western church that I am part of. Thereby, I hope to provide evidence that New Testament Theology does indeed contribute a vital voice in our contemporary discussions on ecology and social justice, and at the same time needs to listen carefully to other voices outside its own field of research.

\subsection{Christian Social Ethics as Participation in the Mission of the Spirit}

It is a common notion in Pauline research that the Spirit is of ethical importance in the apostle's theology: to be Christian is "to walk in the Spirit". In addition, current research has shown that the community of saints plays a vital role in the process of "sanctification" and is of essential importance for it (Samara 2006; Rabens 2010, pp. 171-202). Thereby, the process of developing a life in the Spirit is not an interaction only between the Spirit and the believer, but rather this process is enhanced by the community of believers: "to walk in the Spirit" always comprises a social dimension.

However, in Romans 8.18-30, the issue at stake is not a person's (or community's) walk in the Spirit (as it is e.g., in Gal. 5.16-25); rather, the issue at stake is the mission of the Spirit leading him into solidarity with this creation. It seems that Paul, as well as other biblical authors, tends to associate the cosmic and social aspect of salvation repeatedly with the work of the Spirit (e.g., Is. 32.15-20). Therefore, it perhaps would be adequate to state that Romans 8.18-30 represents a passage that is more likely asking its readers to walk with the Spirit, because in this passage, Paul primarily speaks of the work of the Spirit and not of the believers' responsibility to life according to the Spirit. Hence, a "pneumatological ethics" based on Romans 8.18-30 orients itself along the Spirit's solidarity and intercession for a creation that is suffering and groaning for liberation and thereby is concerned not only with the transformation of a person's character but also with the eschatological liberation of creation to the newness of life in fellowship with the children of God (Rom. 8.21). Even if the text does not provide any clear instructions concerning ethical behaviour to its readers, it is evident from the larger Pauline context that it encourages them to participate in the Spirit's mission in this world: the church is to be where the Spirit is, and the Spirit is in solidarity with this suffering world (cf. Rm. 8:14). Further, throughout the biblical canon, God's redeeming and liberating intervention in this world becomes paradigmatic for the community of faith's ethics (Wenk 2000, pp. 203-7).

It is at this stage that scholars from the field of New Testament Theology need to listen to voices other than their own: as mentioned above, in Romans 8.18-30, Paul develops a systematic approach neither to a Christian social ethics nor to an eco-theology, he merely defines the cosmic frame within which he develops both his soteriology and his particular ethical advice later on in his letter (Rm. 12-15). However, with his emphasis on the groaning and the solidarity of the Spirit with a suffering creation, as well as with the participatory 
language throughout the entire text, the starting point for any Christian social ethics and eco-theology based on Romans 8.18-30 is precisely in listening carefully and emphatically to the voices of those suffering. Since the "soteriological frame" of Romans 8.18-30 is of cosmic dimension, the many tongues to listen to comprise people suffering, i.e., by oppression, hunger, war, and injustice but also animal life, plants, water, and other elements of nature suffering due to human exploitation. Some of these voices are "non-verbal" or in need of being given a voice in order to be heard in our time. There may well be people outside from the academic guild that are more competent in hearing these voices, and they may more adequately speak on their behalf than do scholars from the field of New Testament Theology. There are also voices from the theological guild that advance a pneumatological based eco-theology, i.e., Wallace, who develops a nature-based pneumatology that will bring healing and peace for a planet suffering violence and separation (Wallace 1996), or Bergmann, who argues that the Spirit is the principle agent of salvation as well as the perfector and liberator of nature. In order to sustain his thesis, he develops a methodology by listening to voices from the past (Gregory of Nazianzus), then bringing it in dialogue with contemporary voices in order to address the ecological crisis of our days. (Bergmann 2005), or Swoboda, who develops a Pentecostal theology of a Spirit-baptized creation (Swoboda 2013), however, with basically no reference to Romans 8.18-30.

Further, the participatory language of the text especially helps people living in the West to look at life through fresh lenses and enhances our awareness that we do not exist without the soil upon which we stand and without the air we breathe; we co-inhabit this world. Through the indwelling of the Spirit in all of creation, we participate in creation, as we participate in the resurrection life of Christ. Again, we can learn from both voices of the past (i.e., Saint Francis of Assisi or John Muir) and present (Midgley 1978; Wallace 1996) how we can best live in a creation in which we participate.

However, the Spirit's mission in this world is characterized not only by his solidarity with life threatened but also by stirring up hope and interceding on behalf of those suffering.

\subsection{Hope in the Spirit and Interceding for Those Suffering}

The hope that a church, participating in the mission of the Spirit (sharing in his ethos), is stirring up the lives of those suffering is not simply a comfort for a better life then and there. Rather, a church embracing the ethos of the Spirit lives hope in the midst of a world that is hopeless, for it knows of the life-giving power of the Spirit as well as of his emphatic solidarity and intercession on behalf of this world (Johnson 2011, pp. 96-129): the ultimate reality for all creation is made manifest in and through the church here and now. Again, such hope is rooted both in the actual experience of the Spirit's presence in the church as well as in the resurrection of Jesus, anticipating thereby the resurrection of all of creation towards its final liberation and glory in the presence of God. However, such hope will lead the church at times to live in contradiction to its surrounding culture, for any community proclaiming a hope beyond the present reality automatically finds itself criticizing this present reality; it identifies this current reality as passing and therefore ultimately not as indispensable or absolutely necessary. This is what makes the church a prophetic voice; it will speak on behalf of those that cannot speak for themselves. It will stir up a hope in those that have no hope-and solidarity is the way to do so.

\section{Conclusions}

This reading of Romans 8.18-30 represents a different approach to a theology of the Spirit than is often reflected by both contemporary academic and non-academic voices. Romans 8.18-30 unveils Paul's understanding of the mission of the Spirit (ethos) in a threefold way:

- $\quad(\operatorname{Re})$ creation and liberation of all of creation

- Solidarity by groaning with creation

- Intercession on behalf of creation. 
The passage reflects a cosmic understanding of salvation; thereby, the text addresses issues such as the justice for and redemption of the victims of sin, including all of creation. Such a soteriology adds to the Christian understanding of "the incarnation of the word of God" the "incarnation of the Spirit of God". A more pneumatological formulated soteriology, based on Romans 8.18-30, will also have implications for the mission and ethics of the church, for it comprises the overcoming of sin so that the victims of injustice, abuse, and violence (including nature) will be liberated to their final freedom together with the children of God. A community of faith that is to embrace the ethos of the Spirit, or to walk with the Spirit, is to take side with all forms of life that are threatened.

As noticed earlier, in Romans 8.18-30, Paul does not elucidate a detailed pneumatological social ethics nor a systematic pneumatological eco-theology. Paul rather sets the wider cosmic stage for his soteriology and his particular ethical advice later on in the letter. However, Romans 8.18-30 can nevertheless contribute to the contemporary discussion on social ethics and the ecological crisis, because Paul's cosmic and universal frame "becomes incarnated" in our particular contexts by the Spirit's solidarity with and participation in the suffering creation, as well as with the hope being stirred up based on the resurrection of Jesus. What this solidarity looks like in our particular contexts remains for us to find out together, and we do so by listening to all voices of creation that are groaning and in pain, eagerly expecting their liberation. In order to hear these voices, it may be necessary for many of us to learn new languages and to speak new tongues: any social ethics or pneumatological oriented eco-theology based on Romans 8.18-30 begins not with writing a new approach to the topic but with listening to those suffering.

Lastly, Romans 8.18-30 has much to contribute to any discussion of empowerment through the Spirit, for it provides a definition of power that honours any Spirit-prompted solidarity with all forms of suffering and pain in the same way as those experiences in which the destructive forces of sin are proleptically overcome already here and now. Perhaps the churches in the West have much need for such a kind of power that is expressed in solidarity with those groaning for their final liberation, and they have much need to seek the guiding of the Spirit for new ways yet to walk with the Spirit.

Scholars working in the field of New Testament theology should not hesitate to "add their voice" to the contemporary discourse on the Christian faith, because it is only in listening to the voices from past and present that the Christian community will be able to face the challenges of our time. However, biblical scholars (as well as all theologians) should be well-acquainted with the many other voices impacting contemporary spirituality and the discourse on the Christian faith, both academic and non-academic. Sometimes scholars working in the field of New Testament theology will represent the prophetic voice in this dialogue, and sometimes other voices will help them hearing the voice of the New Testament authors in a clearer way.

Funding: This research received no external funding.

Institutional Review Board Statement: Not applicable.

Informed Consent Statement: Not applicable.

Data Availability Statement: Not applicable.

Conflicts of Interest: The author declares not conflict of interest.

\section{Notes}

1 The German ethicist Hans G. Ulrich has performed ground-breaking work in this regard. He differentiates between a Christian social-ethic, evidenced in a certain program, and the lived ethos of a Christian community. The ethos is more foundational and reflected in rituals and acts that are not necessarily part of an explicit ethical discourse (Ulrich 2007, pp. 48-49; Ulrich 2009, pp. 435-48).

2 An "incarnational pneumatology" becomes even more apparent in developing it from the Old Testament where the Spirit constantly works towards the materialization of God's desire to give life to that which is without life—or threatened by the forces of chaos. 
3 While Gordon Fee emphasises the collective and ethical dimension of the work of the Spirit in this passage, he neglects to highlight the eschatological one (Fee 1994, p. 517).

4 Dunn understands the motive of the intercession by the Spirit as reflecting early Jewish parallels speaking of the intercession of angels, something that is found also in Hebrews (Dunn 1998, p. 308).

5 For a discussion of the fact that the resurrection of Jesus is never explicitly attributed to the Spirit other than in Romans 8.11and, therefore, the belief in resurrection by the Spirit is, so to speak, the result of their belief in the resurrection of Jesus, since Jesus had been raised the early Christians had to believe that the Spirit had been given to them, cf. Yates, Spirit and Creation, pp. 148-51.

6 Macchia speaks in this context of the cosmic dimension of Spirit Baptism (Macchia 2006, pp. 102-7).

7 For the argument that this "groaning of the Spirit" refers to glossolalia, cf. Macchia (1992).

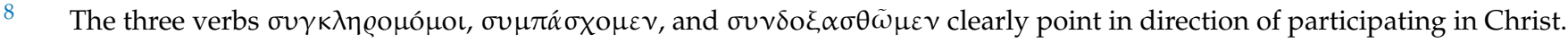

9 Very well-developed by Moltmann: “Er offenbarte seine Identität bei denen, die ihre Identität verloren hatten ... und erkennt sich als den Menschensohn bei denen, die ihrer Menschlichkeit beraubt sind. (...) Das Geselligkeitsprinzip des Gekreuzigten aber ist die Gesellung zu den anderen und die Solidarität mit denen, die zu Fremden wurden und zu anderen gemacht worden sind". (Moltmann 1972), S. 32-33]. Cf. (Wiesel 1982, pp. 93-94). However, Wiesel's argumentation is not Christological but theological in the broadest sense: God is hanging at the gallows; God is that boy that was executed-and therefore God has been killed.

\section{References}

Bauckham, Richard. 2003. New Testamen Theology: The Theology of the Book of Revbelation, 10th ed. Edited by James Dunn. Cambridge: CUP.

Bazzell, Pascal. 2015. Urban Ecclesiology, Famila Deim and a Fillipino Community Facing Homelessness. New York: Bloomsburry.

Benson, Ezekiel. 2018. How to Fellowship with the Holy Spirit to Activate E Live in Divine Prosperity, Divine Success E Divine Favour, Independently Published.

Bergmann, Sigurd. 2005. The Spirit as Liberator of Nature. Grand Rapids: Wm. B. Eerdmans.

Bernhardt, Andrew. 2015. How to Gain Victory over Sin. Knowing the Sanctification of the Holy Spirit. Scotts Valley: CreateSpace Independent Publishing Platform.

Bultmann, Rudolf. 1964. غ̇ $\lambda \pi i \zeta \kappa \tau \lambda$. In Theological Dictionary of the New Testament. Edited by Gerhard Kittel and Gerhard Friedrichs. Grand Rapids: Eerdmans, Vol. II, Seitenzahl.

Dunn, James. 1998. The Theology of Paul the Apostle. Grand Rapids: Eerdmans.

Fee, Gordon. 1994. God's Empowering Presence. The Holy Spirit in the Letters of Paul. Peabody: Hendrickson.

Haacker, Klaus. 2003. The Theology of Paul's Letter to the Romans. Cambridge: CUP.

Hagin, Kenneth. 2012. The Believer's Authority, 2nd ed. Tulsa: Rhema, First Publish 1985.

Heimbach-Steins, Marianne, and Georg Steins. 2012. Bibelhermeneutik und Christliche Sozialethik. Stuttart: Kohlhammer.

Johnson, Luke Timothy. 2011. Prophetic Jesus, Prophetic Chruc h. The Challenge of Luke-Acgts to Contemporary Christians. Grand Rapdis: Eerdmans.

Käsemann, Ernst. 1971. Perspectives on Paul. London: SCM Press.

Macchia, Frank. 1992. Sighs to Deep for Words. Towards a Theology of Glossalalia. Journal of Pentecostal Theology 1: 47-73. [CrossRef]

Macchia, Frank. 2006. Baptized in the Spirit. A Global Pentecostal Theology. Grand Rapids: Zondervan.

Macchia, Frank. 2010. Justified in the Spirit. Creation, Redemption and the Triune God. Grand Rapids: Eerdmans.

Medic, Praying, and Silvia Blain. 2013. Divine Healing Made Simple: Simplifying the Supernatural to Make Healing and Miracles as Part of Your Everyday Life. Gilbert: Inkity Press.

Menzies, Robert P. 1991. The Devlopment of Early Christiabn Pneumatology. With Special Reference to Luke-Acts. Sheffield: SAP.

Metzger, Bruce M. 1983. The Fourth Book of Ezra. In The Old Testament Pseudepigrapha. Edited by James H. Charlesworth. New York: Doubleday, vol. 1, pp. 517-59.

Midgley, Mary. 1978. Beast and Man: The Roots of Human Nature. Ithaca: Cornell University Press.

Moltmann, Jürgen. 1972. Der gekreuzigte Gott: Das Kreuz Christi als Grund und Kritik ch Ristlicher Theologie. München: Kaiser Verlag.

Rabens, Volker. 2010. The Holy Spirit and Ethics in Paul. Tübingen: Mohr Siebeck.

Rabens, Volker, Jacquelin N. Grey, and Mariam Mamell, eds. 2021. Key Approaches to Biblical Ethics. An Interdiciplinary Dialogue. Leiden: Brill.

Roberts, Oral. 2002. When You See the Invisible, you Can Do the Impossible. Shippensburg: Desteinity Image.

Samara, James G. 2006. Being Conformed to Christ in Community. A Study of Maturity, Maturation and the Local Chruch in the Undisputed Pauline Epistles. London: T \& T Clark.

Story, J. Lyle. 2021. Christian Affections in Romans 8. Journal of Pentecostal Theology 30: 201-20. [CrossRef]

Swoboda, Aaron Jason. 2013. Tongues and Trees. Toward a Pentecostal Ecological Theology. Dorset: Deo Publising.

Ulrich, Hans G. 2007. Wie Geschöpfe leben. Konturen Evangelischer Ethik. Berlin: LIT.

Ulrich, Hans G. 2009. Ethik lernen im Vaterunser. Das Gebet als paradigmatische Praxis einer Lebensform. In Denkraum Katechismus. FS für Oswald Bayer. Edited by Johannes Von Lupke and Edgar Thaidigsmann. Tübingen: Mohr.

Wallace, Mark I. 1996. Fragments of the Spirit. Nature, Violence, and the Renewal of Creation. New York: Continuum. 
Wenk, Matthias. 2000. Community Forming Power: The Socio-Ethical Role of the Spirit in Luke-Acts. London: T \& T Cklark. Wiesel, Eli. 1982. Die Nacht zu Begraben. München: Bechtle Verlag.

Wilckens, Ulrich. 1993. Der Brief an Die Römer (EKK). Zürich: Enzinger.

Wright, Nicholas Thomas. 2003. The Resurrection of the Son of God. Minneapolis: Fortress Press.

Yates, John W. 2008. The Spirit and Creation in Paul. Tübingen: Mohr Siebeck.

Ziauddin, Bruno. 2021. Wo stehe ich? Eine politische Abrechnung mit mir selbst. Das Magazin 4: 10-20. 